\title{
PENGARUH KINERJA KEUANGAN, FINANCING TO DEPOSIT RATIO(FDR), MODAL SENDIRI, TERHADAPPEMBIAYAAN MUDHARABAH PERBANKAN SYARIAH YANG ADA DI INDONESIA
}

\author{
${ }^{1}$ Dinda Lestari Purba, ${ }^{2}$ Jalilah Ilmiha \\ ${ }^{1,2}$ Universitas Islam Sumatera Utara \\ ${ }^{1}$ dindalestari190420@gmail.com, ${ }^{2}$ Jalila.ilmiha@fe.uisu.ac.id
}

\begin{abstract}
The background to the problem of this study is the difference in each influence of the variable $x$ on the variable y studied in Islamic commercial bank companies in Indonesia for the 2015-2019 period. The purpose of this study is to analyze the effect of ROA, FDR, Own Capital on Islamic Banking Mudharabah Financing in Indonesia in 2015-2019. The data analysis method used to test the hypothesis is descriptive analysis test, classical assumption test, multiple linear regression analysis, and hypothesis testing. The results showed that the variables ROA, FDR, and Own Capital simultaneously had a significant influence on Mudharabah Financing. Meanwhile, the effect is partially different. Own Capital has a significant effect on Mudharabah Financing. ROA and FDR have no significant effect on mudharabah financing.
\end{abstract}

Keywords : Return On Asset (ROA), Financing To Deposit Ratio (FDR), Own Capital, Mudharabah Financing.

ABSTRAK : Latar belakang masalah dari penelitian ini ialah adanya perbedaan dari setiap pengaruh variabel $x$ terhadap variabel y yang di teliti pada perusahaan bank umum syariah yang ada di indonesia periode 2015-2019. Tujuan penelitian ini adalah untuk menganalisa pengaruh Return On Asset (ROA), Financing To Deposit Ratio (FDR), Modal Sendiri terhadap Pembiayaan Mudharabah Perbankan Syariah yang ada di Indonesia tahun 2015-2019. Metode analisis data yang digunakan untuk menguji hipotesis adalah uji analisis deskriptif, uji asumsi klasik, uji analisis regresi linear berganda, dan uji hipotesis. Hasil penelitian menunjukkan bahwa variabel Return On Asset (ROA), Financing To Deposit Ratio (FDR), dan Modal Sendiri secara simultan memberikan pengaruh signifikan terhadap Pembiayaan Mudharabah. Sedangkan secara parsial pengaruhnya berbeda-beda. Modal Sendiri berpengaruh signifikan terhadap Pembiayaan Mudharabah. Return On Asset (ROA) dan Financing To Deposit Ratio (FDR) berpengaruh tidak signifikan terhadap pembiayaan mudharabah.

Kata Kunci : Return On Asset (ROA), Financing To Deposit Ratio (FDR), Modal Sendiri, Pembiayaan Mudharabah.

\section{Pendahuluan}

Perkembangan perbankan di Indonesia meningkat semakin cepat seiring dengan kebutuhan masyarakat akan jasa perbankan. Masyarakat menuntut kecepatan dan kemudahan seiring dengan mobilitas masyarakat yang tinggi. Bank menawarkan berbagai layanan yang mempermudah masyarakat dalam bertransaksi.

Dalam meningkatkan perekonomian masyarakat, bank sebagai lembaga keuangan memiliki peranan yang besar yaitu sebagai perantara dari orang yang memiliki kelebihan dana kepada orang yang membutuhkan dana/modal. Sesuai dengan 3 fungsi perbankan yaitu menerima simpanan, memberikan pinjaman, dan memberikan jasa pengiriman uang. Ketiga fungsi tersebut diharapkan dapat membantu memperlancar transaksi dalam mengembangkan perekonomian masyarakat. (Setiyabudi, 2017)

Dalam perbankan syariah penyimpanan dana disebut penghimpunan. Sedangkan penyaluran dana disebut pembiayaan. Manfaat bank syariah ialah mengumpulkan uang, menyebarkan uang, serta menyiapkan jasa yang sesuai dengan aturan agama islam. Bentuk model pembiayaan perbankan berbasis syariah 
sangat di tekankan pada pembiayaan yang menggunakan landasan bagi hasil yang memusatkan motif korelasi antara nasabah dengan perbankan.

Pembiayaan mudharabah merupakan bentuk kerjasama antara dua pihak atau lebih dimana pemilik modal (shaibul mal) mempercayakan sejumlah modal kepada pengelola (mudharib) dengan suatu perjanjian pembagian keuntungan. Bentuk ini menegaskan kerjasama dalam panduan kontribusi $100 \%$ modal kas dari shaibul al-maal dan keahlian dari mudharib (Pasaribu, 2019)

Salah satu acuan bagi perbankan untuk meningkatkan pembiayaan ialah dengan melihat tingkat pendapatan bank tersebut, karena semakin meningkatnya pendapatan maka semakin meningkatnya asset yang dapat disalurkan melalui pembiayaan. Semakin meningkatnya Return On Asset (ROA) maka semakin meningkatnya pembiayaan. Roa dapat memberikan informasi seberapa efisien suatu bank dalam melakukan kegiatan usahanya, karena rasio ini mengindikasikan seberapa besar keuntungan yang dapat diperoleh rata-rata terhadap setiap rupiah asetnya. Semakin besar ROA maka keuntungan yang diperoleh bank semakin besar yang memampukan bank untuk menyalurkan pembiayaan lebih banyak lagi. (Trimulia, 2016)

Dan dalam perbankan syariah tidak ada istilah kredit (Loan) yang ada pembiayaan (Financing). Sehingga dalam perbankan syariah LDR disebut FDR. Sebagai tolak ukur untuk melihat keefektifan sebuah bank dalam menjalankan fungsinya sebagai lembaga intermediasi dapat dilihat dari nilai Financing To Deposit Ratio (FDR) bank tersebut. Sebagian praktis perbankan menyepakati bahwa batas aman dari FDR suatu bank adalah sekitar $80 \%$ namun batas toleransi berkisaran antara $85 \%$ - $100 \%$ (Trisnadi, 2014) dan dalam penelitian (Rahman \& Apandi, 2015) mengatakan bahwa apabila FDR meningkat maka pembiayaan mudharabah akan naik, begitu juga sebailknya apabila FDR menurun maka pembiayaan mudharabah akan menurun.

Modal dinyatakan sebagai aspek penting bagi suatu unit usaha bank karena digunakan untuk memenuhi kebutuhan dalam setiap aktivitasnya. Setiap penciptaan aktiva dapat berpotensi menciptakan keuntungan dan menimbulkan terjadinya resiko kerugian terutama yang berasal dari dana pihak ketiga. Semakin bagus sistem permodalan bank syariah maka akan membentuk kepercayaan yang kuat dari masyarakat sehingga dapat mempengaruhi keputusan nasabah dalam melakukan pembiayaan. Dalam penelitian (Nurul Syahfitri, 2019:18) apabila modal sendiri meningkat maka jumlah pembiayaan mudharabah akan menurun dan sebaliknya apabila modal sendiri menurun maka pembiayaan mudharabah akan meningkat.

Berdasarkan penelitian yang terdahulu, terdapat perbedaan hasil penelitian terhadap fenomena yang dapat disimpulkan bahwa tidak semua kejadian sesuai dengan teori yang ada. Hal ini di perkuat oleh hasil penelitian terdahulu. Peneliti di atas menunjukkan bahwa hasil penelitian memiliki pengaruh yang berbeda-beda dari setiap pengaruh variabel $\mathrm{x}$ terhadap variabel y yang di teliti pada perusahaan bank umum syariah.

Berdasarkan fenomena diatas maka yang menjadi pokok permasalahan yang akan diungkap dalam penelitian ini adalah:

a. Apakah Return On Asset (ROA) berpengaruh terhadap pembiayaan mudharabah pada bank umum syariah.

b. Apakah Financing To Deposit Ratio (FDR) berpengaruh terhadap pembiayaan mudharabah pada bank umum syariah.

c. Apakah modal sendiri berpengaruh terhadap pembiayaan mudharabah pada bank umum syariah.

d. Apakah Return On Asset (ROA), Financing To Deposit Ratio (FDR), modal sendiri berpengaruh terhadap pembiayaan mudharabah pada bank umum syariah.

\section{Tinjauan Pustaka \\ 1) Pembiayaan Mudharabah}

Mudharabah adalah akad yang telah dikenal oleh umat muslim sejak zaman nabi, bahkan telah dipraktikkan oleh bangsa arab sebelum turunnya islam. Ketika nabi Muhammad SAW berprofesi sebagai pedagang, ia melakukan akad mudharabah dengan khadijah. Dengan demikian, ditinjau dari segi hukum islam, maka praktik mudharabah ini dibolehkan, baik menurut Alquran, sunnah, maupun ijma'.

Pembiayaan mudharabah merupakan perjanjian atas sesuatu jenis perkongsian, dimana pihak pertama (shaibul maal) menyediakan dana dan pihak kedua (mudharib) bertanggung jawab atas pengelolaan usaha. Keuntungan hasil usaha dibagi sesuai dengan nisbah porsi bagi hasil yang telah disepakati 
bersama sejak awal, maka kalau mengalami kerugian shahibul maal akan kehilangan sebagian imbalan dari hasil kerja keras dan managerial skill selama proyek berlangsung. Mudharabah disebut juga qiradh yang berarti "memutuskan". Dalam hal ini, si pemilik modal telah memutuskan untuk menyerahkan sejumlah uang untuk diperdagangkannya berupa barangbarang dan memutuskan sekalian sebagian dari keuntungan bagi pihak kedua orang yang ber akad Qiradh ini.

\section{2) Return On Asset (ROA)}

Return on Asset (ROA) atau lebih dikenal dengan nama Return On Investment (ROI) merupakan rasio yang menunjukkan hasil (return) atas jumlah aktiva yang digunakan dalam perusahaan. Rasio ini juga merupakan suatu ukuran tentang efektivitas manajemen dalam mengelola investasinya. Semakin kecil (rendah) rasio ini, semakin kurang baik demikian pulak sebaliknya. (Muhammad Fajar, 2020)

ROA merupakan salah satu rasio keuangan atau profitabilitas yang digunakan untuk mengukur efektifitas perbankan didalam menghasilkan keuntungan. ROA merupakan rasio antara laba bersih setelah pajak terhadap total aset bank. Semakin besar nilai ROA pada bank, maka semakin besar pula tingkat keuntungan yang dicapai bank tersebut dan semakin baik posisi bank tersebut dari segi pengamanan aset. Hasil penelitian menyatakan bahwa ROA berpengaruh positif terhadap pembiayaan yang disalurkan (WIYANTI, 2018)

$$
\text { ROA }=\frac{\text { Laba Bersih Setelah Pajak }}{\text { Total Aktiva }} \times 100 \%
$$

\section{3) Financing to Deposit Ratio (FDR)}

Financing to deposit ratio (FDR) adalah rasio yang mengukur kemampuan bank syariah dalam kemampuan menjalankan fungsi intermediasi secara baik, dapat digunakan rasio FDR sebagai indikatornya. semakin tinggi rasio FDR maka bank tersebut semakin baik dalam menjalankan fungsi intermediasi nya. sebagian praktis perbankan menyepakati bahwa batas aman dari FDR suatu bank adalah sekitar $80 \%$ namun batas toleransi berkisar antara $85 \%$ 100\% (Trisnadi, 2014)

Indikator untuk mengetahui likuid atau tidaknya sebuah bank dapat dilihat dari rasio FDR bank tersebut. FDR sebenarnya sama dengan Leon to Deposit Ratio dalam bank konvensional, perbedaan penyebutan ini dikarenakan dalam bank syariah tidak ada yang namanya loan atau pinjaman melainkan disebut dengan Financing atau pembiayaan. Bank dikatakan likuid ketika mampu memenuhi semua kewajiban hutangnya dan memenuhi permintaan kebutuhan dana yang diajukan nasabah tanpa adanya penangguhan dalam pemberian dana melalui pembiayaan tersebut.

$$
\begin{gathered}
\mathrm{FDR}=\frac{\text { Jumlah pembiayaan yang disalurkan }}{\text { Dana yang diterima bank }} \\
100
\end{gathered} \times
$$

\section{4) Modal Sendiri}

Modal merupakan faktor yang sangat penting bagi perkembangan dan kemajuan bank sekaligus menjaga kepercayaan masyarakat. Dana modal dapat digunakan untuk pembelian gedung, tanah, perlengkapan, dan sebagainya. selain itu, modal juga dapat digunakan untuk hal-hal yang produkstif yaitu disalurkan jadi pembiayaan.

Modal sendiri merupakan modal yang berasal dari pemilik perusahaan pada saat mendirikan perusahaan tersebut dan ditanamkan di dalam perusahaan tersebut untuk jangka waktu yang tidak tertentu. modal sendiri dapat berasal dari keuntungan kegiatan operasional perusahaan yang kerap kali modal seperti ini adalah merupakan bentuk penyertaan modal sebagai bukti kepemilikan seseorang di dalam suatu perusahaan atas penyertaan modal yang diberikannya pada perusahaan tersebut.

\section{Metode Penelitian}

1) Populasi dalam penelitian ini adalah perbankan syariah yang ada di Indonesia periode 2015 - 2019. Jumlah populasi dalam penelitian ini adalah 14 perusahaan perbankan syariah.

2) Sampel merupakan bagian dari populasi yang digunakan sebagai objek dalam penelitian ini. Teknik pengambilan sampel dalam penelitian ini ialah purposive sampling yang mana teknik pengambilan sampel nya dengan pertimbangan atau kriteria tertentu.

3) Lokasi, Objek dan Waktu Penelitian

Penelitian ini dilakukan pada perusahaan perbankan yang terdaftar di Otoritas Jasa Keuangan (OJK) melalui situs www.ojk.go.id

Objek dalam penelitian ini ialah perusahaan perbankan yang diperoleh dari situs resmi milik Otoritas Jasa Keuangan (OJK).

4) Teknik Pengumpulan Data

Teknik pengumpulan data dalam penelitian ini dilakukan dengan menggunakan metode 
purposive sampling. dengan melihat laporan keuangan perusahaan sampel. Dengan teknik ini penulis mengumpulkan data laporan keuangan tahunan perbankan dari tahun 2015-2019. Data diperoleh melalui situs resmi Otorita Jasa keuangan (OJK) www.go.id.

5) Teknik Analisis Data

Teknik analisis data yang dilakukan dalam penelitian ini adalah analisis statistik dan analisis data dilakukan dengan analisis deskriptif yang terlebih dahulu dilakukan pengujian normalitas, uji asumsi klasik dan uji hipotesis. Data dalam penelitian ini diolah dengan menggunakan program SPSS versi 20.

\section{Hasil Penelitian Dan Temuan}

Berdasarkan hasil analisis yang telah dilakukan pada analisis deskriptif dengan menggunakan SPSS versi 23, maka diperoleh pembahasan sebagai berikut:

1) Pengaruh Return On Asset (ROA) terhadap Pembiayaan Mudharabah

Berdasarkan hasil uji hipotesis menunjukkan bahwa ROA berpengaruh tidak signifikan terhadap pembiayaan mudharabah dengan nilai signifikan $0,326>0,05$ dan nilai $t_{\text {hitung }}$ sebesar 1,002 sehingga $\mathrm{H}_{1}$ gagal diterima. Dengan demikian pembiayaan mudharabah yang dilakukan perusahaan tidak ada kaitannya dengan Return On Asset (ROA). Hasil ini sejalan dengan penelitian Diana, Rusydi dan Novi Yolanda (2018) yang menyatakan bahwa ROA tidak berpengaruh terhadap pembiayaan mudharabah.

2) Pengaruh Financing To Deposit Ratio (FDR) Berdasarkan hasil uji hipotesis menunjukkan bahwa FDR berpengaruh tidak signifikan terhadap pembiayaan mudharabah dengan nilai signifikan $0,814>0,05$ dan nilai $t_{\text {hitung }}$ sebesar 0,237 sehingga $\mathrm{H}_{2}$ gagal diterima. Dengan demikian pembiayaan mudharabah yang dilakukan perusahaan tidak ada kaitannya dengan Financing To Deposit Ratio (FDR). Hasil ini sejalan dengan penelitian Wahab (2014) yang mengatakan bahwa FDR tidak berpengaruh positif terhadap pembiayaan mudharabah.

3) Pengaruh Modal Sendiri terhadap Pembiayaan Mudharabah

Berdasarkan hasil uji hipotesis menunjukkan bahwa modal sendiri berpengaruh signifikan terhadap pembiayaan mudharabah dengan nilai signifikan sebesar $0,000<0,05$ dan $\mathrm{t}_{\text {hitung }}$ sebesar 26,206 sehingga $\mathrm{H}_{3}$ diterima. Dengan demikian dapat disimpulkan bahwa, semakin besar modal sendiri maka semakin tinggi pembiayaan mudharabah dan begitu sebaliknya. Dan modal sendiri menjadi salah satu faktor yang sangat berpengaruh. Hasil penelitian ini sejalan denngan hasil penelitian Nurul Syahfitri (2019) yang mengatakan bahwa modal sendiri berpengaruh terhadap pembiayaan mudharabah.

\section{Kesimpulan}

Berdasarkan analisis data dan pembahasan yang telah dikemukakan maka kesimpulan sebagai berikut:

a. Return On Asset (ROA) tidak berpengaruh signifikan terhadap Pembiayaan Mudharabah pada perbankan syariah yang ada di Indonesia.

b. Financing To Deposit Ratio (FDR) tidak berpengaruh signifikan terhadap Pembiayaan Mudharabah pada perbankan syariah yang ada di Indonesia.

c. Modal Sendiri berpengaruh signifikan terhadap Pembiayaan Mudharabah pada perbankan syariah yang ada di Indonesia.

d. Berdasarkan hasil uji simultan dengan menggunakan uji F, diketahui Return On Asset (ROA), Financing To Deposit Ratio (FDR), Modal Sendiri secara bersama-sama atau simultan, berpengaruh signifikan terhadap Pembiayaan Mudharabah.

\section{DAFTAR PUSTAKA}

Anwar, C., \& Miqdad, M. (2017). Pengaruh Dana Pihak Ketiga (DPK), Return On Asset (ROA) Terhadap Pembiayaan Mudharabah Pada Bank Umum Syariah Tahun 20082012. Riset Dan Jurnal Akuntansi, 1(1), 4247.

Hendrasman, D. Y. (2008). ... Sendiri, Non Performing Financing, Prosentase Bagi Hasil Dan Mark Up Keuntungan Terhadap Pembiayaan Pada Perbankan Syariah: Studi kasus Bank Syariah http://repository.uinjkt.ac.id/dspace/handle/1 23456789/11074

Ikhwal, N. (n.d.). Analisis ROA Dan ROE Terhadap Profitabilitas Bank.

Karim, A. (2010). BANK ISLAM (keempat). PT RAJAGRAFINDO PERSADA.

Lestari, Y. putri. (2020). Kemampuan Koneksi Matematis (Tinjauan Terhadap Pendekatan 
Pembelajaran Savi), 53(9), 1689-1699.

Muhammad fajar (p. 11).Pengaruh Resiko Pasar, Resiko Kredit, dan Resiko Operasional terhadap Return On Asset (ROA) pada Perbankan yang terdaftar di Bursa Efek Indonesia (BEI) (2020).

Nur, F., Samalam, A., Mangantar, M., Saerang, I. S., Ekonomi, F., Bisnis, D., Manajemen, J., Sam, U., \& Manado, R. (2018). Pengaruh Return on Asset, Return on Equity Dan Debt To Equity Ratio Terhadap Return Saham Pada Perusahaan Asuransi Di Bei Periode 2012-2016. Jurnal EMBA: Jurnal Riset Ekonomi, Manajemen, Bisnis Dan Akuntansi, 6(4), 3863-3872. https://doi.org/10.35794/emba.v6i4.21912

Nurul, mas'ud waqiah. (2013). Persepsi Masyarakat Terhadap Perawatan Ortodontik Yang Dilakukan Oleh Pihak Non Profesional, 53(9), 1689-1699.

Pasaribu, D. S. O. (2019). Pengaruh fdr, npf, roa dan bopo terhadap pembiayaan mudharabah bank umum syariah di indonesia. 29.

Rachman, Y. T., \& Apandi, A. (2015). Pengaruh Financing to Deposit Ratio ( FDR ), Non Performing Financing ( NPF ), Return On Assets ( ROA ), dan Capital Adequacy Ratio ( CAR ) terhadap Pembiayaan Mudharabah ( Survey pada Bank Syariah yang Listing di Bursa Efek Indonesia pada Tahun. Proceedings ICIEF'15, August 2015, 1504-1521.

Sapti, M. (2019). Kemampuan Koneksi Matematis (Tinjauan Terhadap Pendekatan Pembelajaran Savi), 53(9), 1689-1699.

Saputra, R. (2019). Journal of Chemical Information and Modeling, 53(9), 16891699.

Setiyabudi, A. D. (2017). Analisis pengaruh bagi hasil dan bi.

Syahfitri, N. (2019). Pengaruh Dana Pihak Ketiga Dan Modal Sendiri Terhadap Pembiayaan Mudharabah Pada PT. Bank Umum Syariah.

Trimulia, A. (2016). Pengaruh Return On Asset,Non Performing Financing, dan Dana Pihak Ketiga terhadap Pembiayaan Mudharabah pada perbankan syariah yang ada di indonesia (Vol. 9, Issue 2).

Trisnadi. (2014). Pengaruh Financing To Deposit Ratio (Fdr) Dan Dana Pihak Ketiga (Dpk) Terhadap Pembiayaan Mudharabah. 10.

Wiyanti, L. (2018). Pengaruh Return on Asset
(Roa) Dan Biaya Operasional Pendapatan Operasional (Bopo) Terhadap Tingkat Bagi Hasil Deposito Mudharabah Pada Bank Umum Syariah Di Indonesia Periode 20122016. 2(1), 1-129. 